www.jmscr.igmpublication.org

Impact Factor (SJIF): 6.379

Index Copernicus Value: 71.58

ISSN (e)-2347-176x ISSN (p) 2455-0450

crossrefDOI: https://dx.doi.org/10.18535/jmscr/v6i6.69

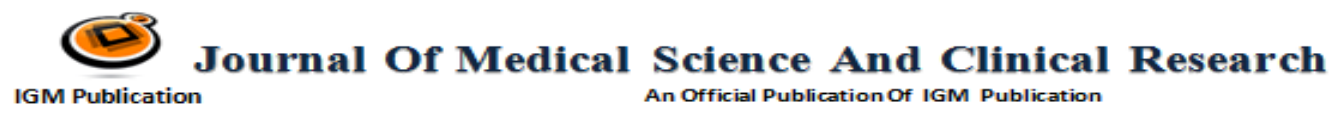

An Official Publication of IGM Publication

\title{
Correlation between Spot Urine Protein-Creatinine Ratio and 24-Hour Urine Protein Estimation in Type 2 Diabetes Mellitus Patients Attending A Tertiary Care Centre in Alappuzha
}

\author{
Authors \\ Sharath Thomas Roy ${ }^{1}$, Dr Udayamma K P ${ }^{2}$ \\ ${ }^{1}$ Junior Resident, ${ }^{2}$ Associate Professor \\ Department of General Medicine Govt. T D Medical College, Alappuzha, Kerala
}

\begin{abstract}
About $20 \%$ of cases of chronic renal failure is due to diabetic nephropathy and is the most common cause of end stage renal disease (ESRD) in many countries. Proteinuria is an independent risk factor for renal diseases and a predictor of ESRD. For the diagnosis and management of chronic renal disease, accurate identification and quantification of proteinuria is very important. An increased proteinuria has both diagnostic and prognostic values in detection and confirmation of renal diseases and to assess response to therapy. Increased proteinuria is associated with an increased risk of progressive renal failure. The gold standard for the quantitative evaluation of proteinuria is the measurement of protein excretion in a $24 \mathrm{hr}$ urine sample. $24 \mathrm{hr}$ urine sample collection is an inconvenient method especially in outpatient setting. An alternate convenient method for evaluation of proteinuria is measurement of protein to creatinine ratio in a spot urine sample. There are a number of studies that show urine spot protein to creatinine ratio (urinary PCR) can replace $24 \mathrm{hr}$ urine protein estimation in the screening and evaluation of diabetic nephropathy.
\end{abstract}

Objectives

1) To determine the correlation of spot urine protein creatinine ratio (PCR) with $24 \mathrm{hr}$ urine protein estimation in patients with type 2 diabetes mellitus.

2) To study the association of biochemical and clinical parameters like serum creatinine, eGFR, glycated hemoglobin, duration of diabetes, presence of diabetic retinopathy with urine PCR in patients with type 2 diabetes mellitus.

Methodology: The design of study is cross sectional study and the study population included Type II Diabetes Mellitus patients attending Medicine OPD, of either sex, in Govt. TDMC, Alappuzha for a period of 12 months from December 2015 to December 2016. The sample size is 73. 24hour urine protein and urine protein creatinine ratio was done in the study population.The patients were also evaluated for associated clinical and biochemical parameters. The data collected was analyzed using a standard statistical package-SPSS version 16.

Results: Seventy three patients with type 2 diabetes mellitus and proteinuria were studied. Maximum number of patients were noted in the age group 41-50 years. Males were more than females in the ratio of 2.04:1. The mean duration of diabetes was 9.24 +/- 6.1 yrs. Majority of patients had a duration of diabetes between 5 - 10 yrs (52.05\%).Ten patients (13.7\%) did not have diabetic retinopathy. Twenty five patients (34.25\%) had nephrotic range proteinuria. There was good correlation between urine PCR and $24 \mathrm{hr}$ urine protein at different levels of GFR. The correlation in different levels of GFR were : (0-15) group : $r=0.784, p=<0.001,(15-30)$ group $: r=0.756, p=$ $<0.001$, (30-60) group : $r=0.725, p=<0.001,>60$ group $: r=0.99, p=<0.001$. Maximum correlation between urine PCR and $24 \mathrm{hr}$ urine protein was seen in the GFR $>60$ group. There was good correlation between urine PCR and $24 \mathrm{hr}$ urine protein at different ranges of proteinuria. The correlation in different levels of proteinuria were: $<300$ $\mathrm{mg}(r=0.93, P<0.001), 300-3500 \mathrm{mg}(r=0.632, P<0.001)$ and $\geq 3500 \mathrm{mg}(r=0.783, P<0.001)$. Maximum correlation between urine PCR and $24 \mathrm{hr}$ urine was seen in the proteinuria group $<300 \mathrm{mg}$. No statistically significant 
correlation was found between HBAlC levels and degree of proteinuria. There was good correlation between degree of diabetic retinopathy and proteinuria. No significant correlation was found between duration of diabetes and urine PCR.

Conclusion: Spot urine protein creatinine ratio can replace $24 \mathrm{hr}$ urine protein estimation in the screening and evaluation of diabetic nephropathy.

\section{Introduction}

In the modern world the burden of diabetes mellitus (DM) is rapidly rising. The main problem with this disease entity is its propensity to incur macro- and microvascular complications over time, crippling both the individual and our resource restricted healthcare system. Diabetic nephropathy (DN) is estimated to affect one-third of individuals with DM and is associated with considerable cardiovascular morbidity and mortality. It is the leading cause of end-stage renal disease (ESRD) worldwide. Unfortunately, the magnitude of this clinical entity continues to grow in association with an expanding diabetic population and remarkably the excess mortality risk of DM is associated almost entirely with the presence of $\mathrm{DN}^{1,2}$. Proteinuria is an independent risk factor for renal diseases and a predictor of end stage renal disease (ESRD) $)^{3}$ Accurate identification and quantification of proteinuria is of prime importance in the diagnosis and management of chronic renal disease. An increased proteinuria is associated with an increased risk of progressive renal failure and is used as both diagnostic and prognostic values in detection and confirmation of renal diseases, or response to therapy ${ }^{4}$.

Early identification of patients at high risk for diabetic nephropathy (DN) is important to intensify the treatment and modify associated risk factors. Measurement of protein excretion in a $24 \mathrm{hr}$ urine collection is the gold standard for the quantitative evaluation of proteinuria. This method carries significant inconvenience for the patient especially in the outpatient setting. So an alternate simpler method was proposed. It is the quantitative evaluation of proteinuria by measurement of protein to creatinine ratio in a spot urine sample which provides a convenient method to assess protein excretion. ${ }^{5}$ The spot urine protein creatinine ratio can be used as a surrogate and may replace $24 \mathrm{hr}$ urine protein estimation in the screening and evaluation of diabetic nephropathy.

\section{Objectives}

\section{Primary Objective}

1. To determine the correlation of spot urine protein creatinine ratio (PCR) with $24 \mathrm{hr}$ urine protein estimation in patients with diabetic nephropathy.

\section{Secondary Objective}

2. To study the association of biochemical and clinical parameters like serum creatinine, eGFR, glycated hemoglobin, duration of diabetes, presence of diabetic retinopathy with urine PCR in patients with diabetic nephropathy.

\section{Materials and Methods}

Study Design: Cross sectional Study

Study Duration: For a period of 1 year after ethical committee clearance (December 2015December 2016)

Study Setting: This study is carried out in patients attending General Medicine OPD in Govt TDMC Alappuzha for a period of 12 months after getting permission from research and ethical committee.

\section{Sample Size: 73}

\section{Study Population}

Type II Diabetes Mellitus patients attending Medicine OPD, of either sex, in Govt. TDMC, Alappuzha

\section{Inclusion Criteria}

- Type 2 Diabetes Mellitus patients with proteinuria.

\section{Exclusion Criteria}

Patients with

- Acute febrile illness 
- Urinary tract infection

- Taking ACEI/ARB

- Glomerulonephritis due to systemic conditions

- Malignancies ,collagen vascular disorders or any other systemic condition causing proteinuria

- Age $<18$ yrs

- Pregnant women

\section{Method of data Collection}

A random sample of male and female patients with type 2 diabetes mellitus satisfying the inclusion and exclusion criteria was selected. Data was collected with the aid of a proforma, which included patient history, clinical parameters like duration of diabetes, prevalence of diabetic retinopathy and biochemical parameters like serum creatinine, eGFR, glycated hemoglobin , urine protein creatinine ratio and $24 \mathrm{hr}$ urine protein. On the test day, in the morning at the start of collection period (6.00 a.m.) patients were asked to void urine and discard this sample (as it contains the overnight urine present in the bladder). Subsequently urine was collected for next $24 \mathrm{hrs}$. The last sample was to be collected on next day at 6.00 a.m. A random sample was also collected on the day of deposition of $24 \mathrm{hr}$ sample (the test day). Urine protein was estimated using Pyrogallol red molybdate method and urine creatinine by modified Jaffe's method .Creatinine clearance was calculated using the MDRD (Modified Diet in Renal Disease) equation : GFR $\left(\mathrm{mL} / \mathrm{min} / 1.73 \mathrm{~m}^{2}\right)=175 \times\left(\mathrm{S}_{\mathrm{cr}}\right)^{-1.154} \times(\text { Age })^{-0.203} \times$ $(0.742$ if female $) \times(1.212$ if African American $)$.

\section{Statistical Analysis}

- The data collected was analyzed using a standard statistical package-SPSS version 16. Spearman's correlation coefficient was used for correlation of numerical variables. Kruskal Wallis test was used for the association between retinopathy and urine PCR.

\section{Results}

This study included 73 patients with type 2 diabetes mellitus who got admitted to the medicine ward of Govt TD Medical College, Alappuzha. Findings in the patients studied were evaluated and tabulated using Microsoft Excel and has been given as Annexure. Statistical analyses were conducted using SPSS 16.0 for Windows (SPSS Inc, Chicago, USA).

\section{Patient Characteristics}

\section{Age wise distribution}

The age of the patients studied ranged from 30 years to 80 years. Mean age of the patients was $51.9+/-10.4$ yrs. Mean age of female and male patients were $51.2+/-10.4 \mathrm{yrs}$ and $52.37+/-10.5$ respectively.

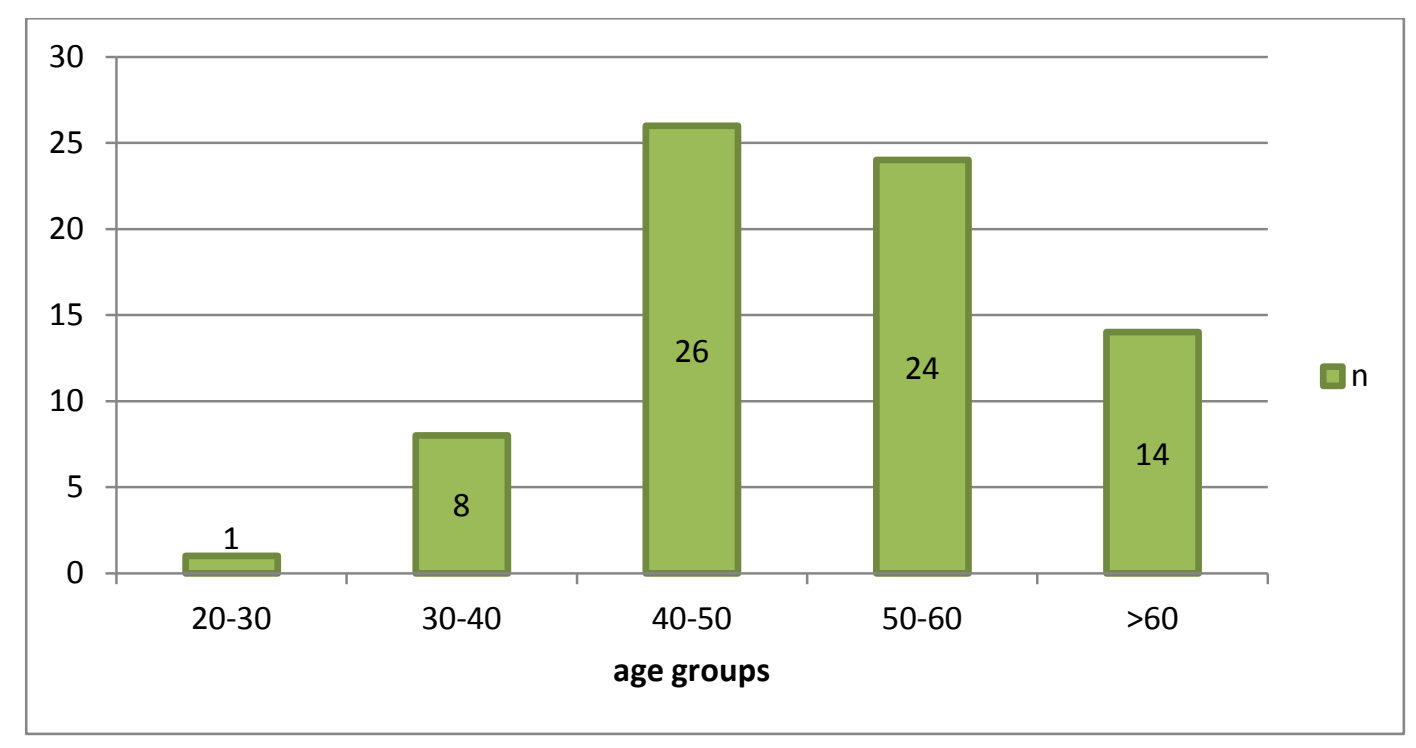

Chart 1: Age wise Distribution of Cases 
Maximum number of patients were noted in the age group 41-50 years i.e., $26(35.1 \%)$ and least in the age group 20-30 years i.e., 1 (1.35\%).

\section{Gender wise distribution}

Of the 73 patients studied, $49(67.1 \%)$ patients were males and $24(32.9 \%)$ patients were females

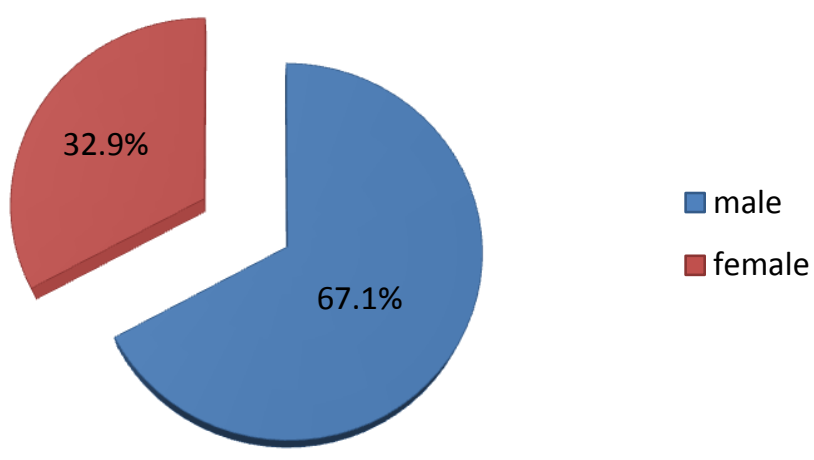

Chart 2: Gender wise distribution of cases

\section{Diabetic Retinopathy}

Of the 73 patients studied, $10(13.7 \%)$ did not have diabetic retinopathy, $9(12.33 \%)$ had proliferative diabetic retinopathy (PDR) and the rest non proliferative diabetic retinopathy (NPDR).

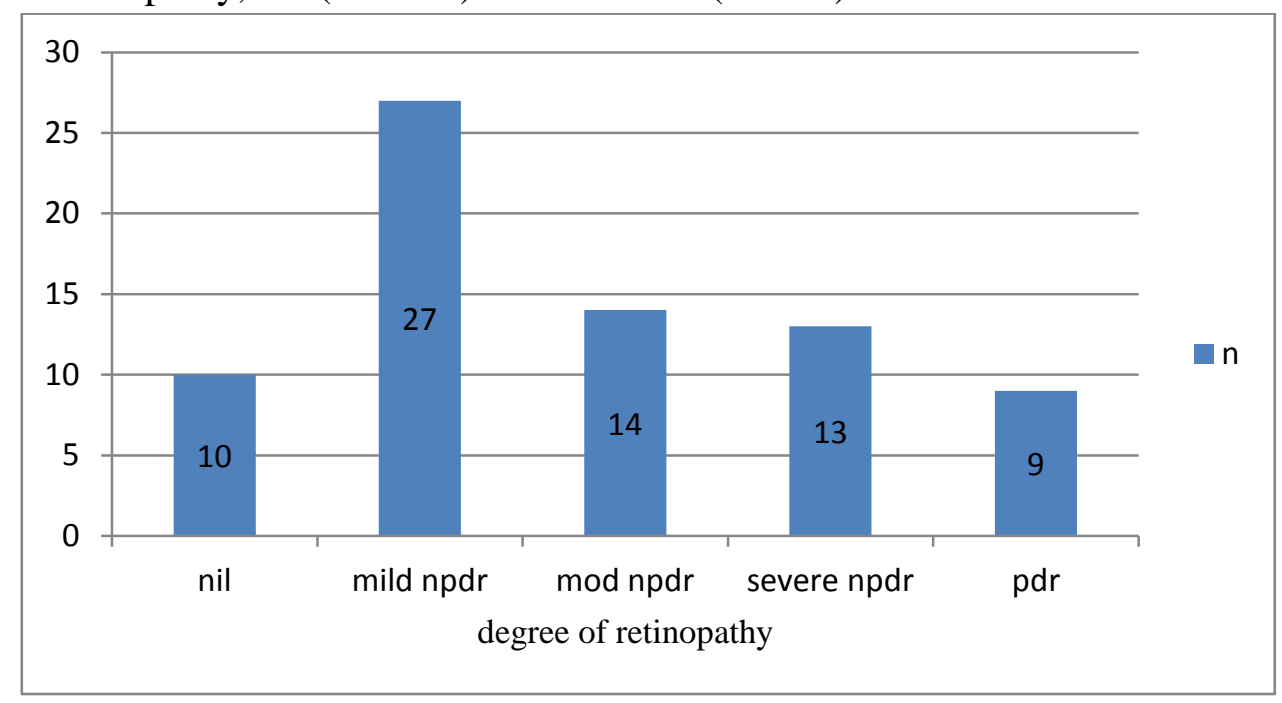

Chart 3 : Frequency distribution based on degree of diabetic retinopathy

Table 1: Percentage of patients based on the degree of retinopathy

\begin{tabular}{|l|c|c|}
\hline Degree of retinopathy & Percentage & No. of patients \\
\hline Mild NPDR & $36.99 \%$ & 27 \\
\hline Moderate NPDR & $19.18 \%$ & 14 \\
\hline Severe NPDR & $17.80 \%$ & 13 \\
\hline PDR & $12.33 \%$ & 9 \\
\hline No retinopathy & $13.70 \%$ & 10 \\
\hline
\end{tabular}

\section{Degree of Proteinuria}

Out of the 73 patients with proteinuria, 25 patients $(34.25 \%)$ had proteinuria of more than $3.5 \mathrm{gms} / 24$ hours and 48 patients $(65.75 \%)$ had proteinuria of less than $3.5 \mathrm{gms} / 24$ hours. 


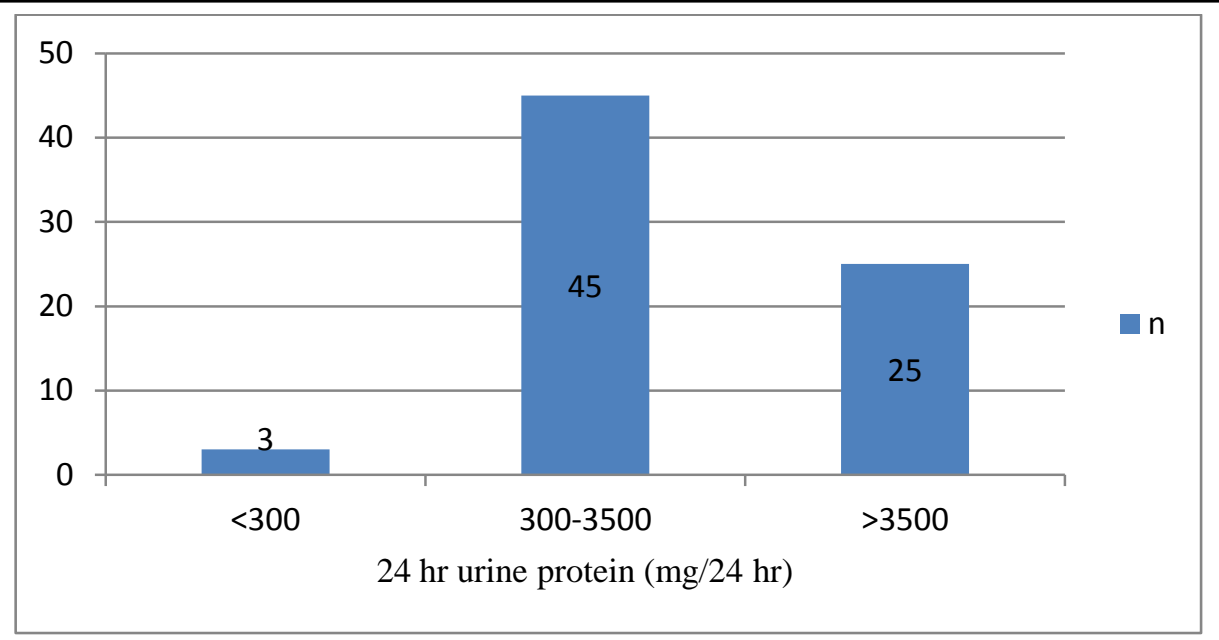

Chart 4 : Frequency distribution based on degree of proteinuria

Table 2: Percentage of patients based on the degree of proteinuria

\begin{tabular}{|l|c|c|}
\hline Degree of proteinuria $\mathbf{( m g / 2 4 h r )}$ & Percentage & No. of patients \\
\hline$<300$ & $4.11 \%$ & 3 \\
\hline $300-3500$ & $61.64 \%$ & 45 \\
\hline$>3500$ & $34.25 \%$ & 25 \\
\hline
\end{tabular}

\section{Creatinine Clearance}

In our study, majority of patients had creatinine clearance (calculated by MDRD equation) between $30-60 \mathrm{ml} / \mathrm{min}^{1} / 1.73 \mathrm{~m}^{-2}$ - 25 patients $(34.24 \%)$.

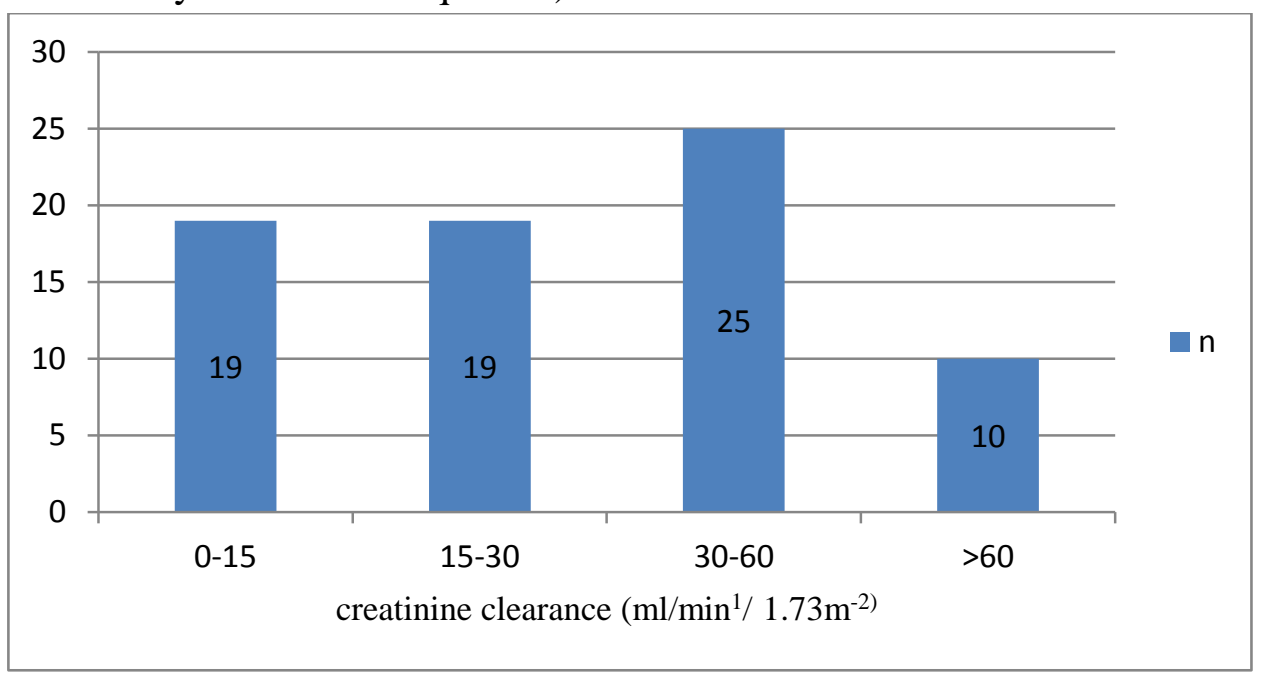

Chart 5 : Frequency distribution based on creatinine clearance

Table 3 : Percentage of patients based on creatinine clearance

\begin{tabular}{|l|c|c|}
\hline Creatinine clearance $\left(\mathbf{m l} / \mathbf{m i n}^{\mathbf{1}} / \mathbf{1 . 7 3} \mathbf{m}^{-\mathbf{2}}\right)$ & Percentage & No. of patients \\
\hline $0-15$ & $26.03 \%$ & 19 \\
\hline $15-30$ & $27.03 \%$ & 19 \\
\hline $30-60$ & $34.24 \%$ & 25 \\
\hline$>60$ & $13.70 \%$ & 10 \\
\hline
\end{tabular}

\section{Duration of Diabetes}

In our study, majority of patients had duration of diabetes between 5 to $10 \mathrm{yrs}-38$ patients
$(52.05 \%)$. The mean duration of diabetes was 9.24 $+/-6.1 \mathrm{yrs}$. 


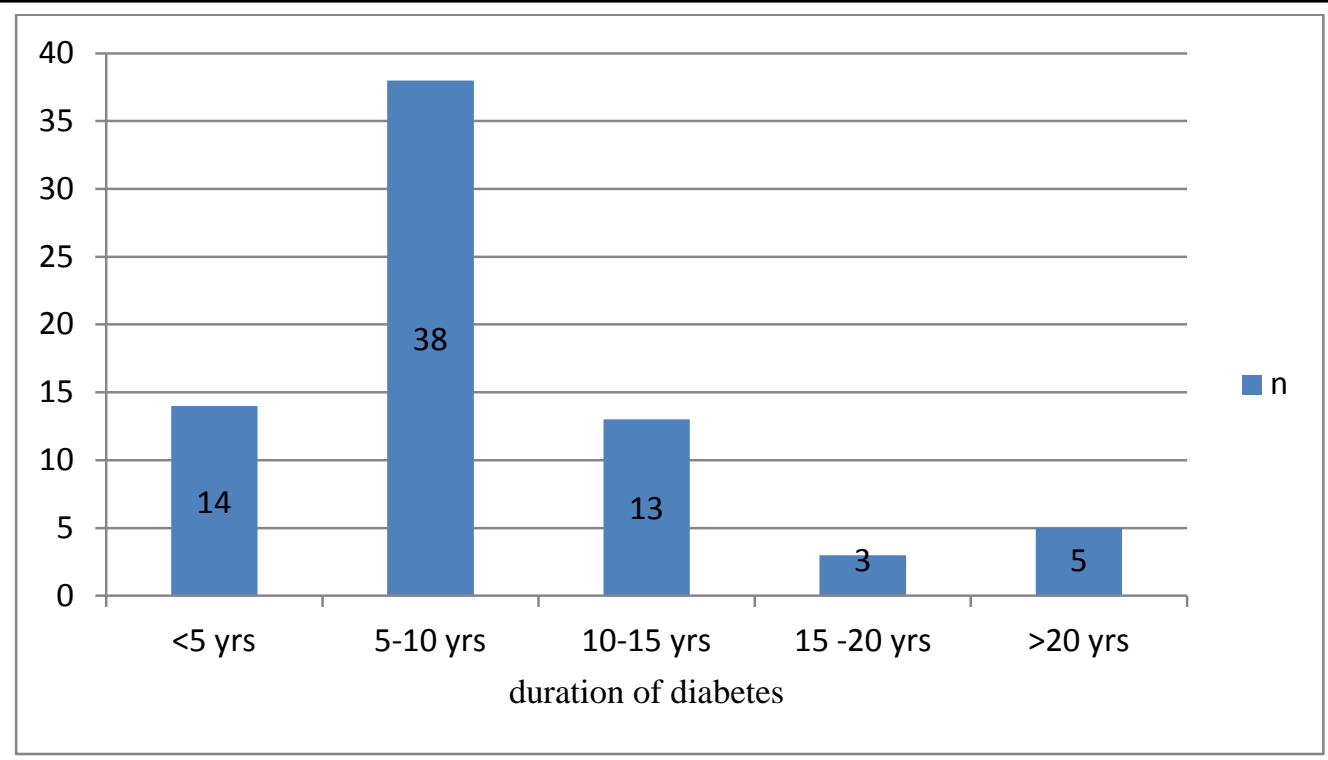

Chart 6: Frequency distribution based on duration of diabetes

Table 4 : Percentage of patients based on duration of diabetes

\begin{tabular}{|l|c|c|}
\hline Duration of diabetes (yrs) & Percentage & No. of patients \\
\hline$<5$ & $19.18 \%$ & 14 \\
\hline $5-10$ & $52.05 \%$ & 38 \\
\hline $10-15$ & $17.81 \%$ & 13 \\
\hline $15-20$ & $4.11 \%$ & 3 \\
\hline$>20$ & $6.85 \%$ & 5 \\
\hline
\end{tabular}

\section{Correlation between Urine PCR and $24 \mathrm{Hr}$ Urine Protein}

There was a significant positive correlation between urine PCR and $24 \mathrm{hr}$ urine protein in our study $(\mathrm{r}=0.87$ $\mathrm{p}<0.001)$.

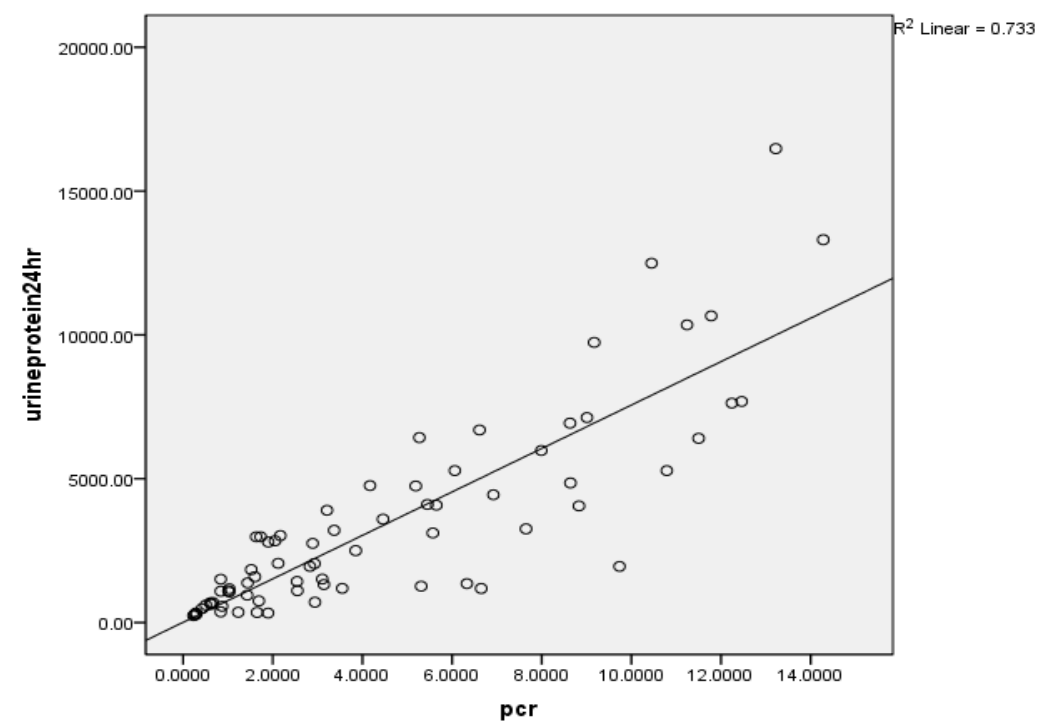

Chart 7 : Correlation between urine PCR and $24 \mathrm{hr}$ urine protein

Correlation coefficient $(r): 0.87$

P value : $<0.001$ 


\section{JMSCR Vol||06||Issue||06||Page 412-425||June}

\section{Correlation between Urine PCR and Serum Creatinine}

A significant positive correlation was found between urine PCR and serum creatinine in our study $(\mathrm{r}=$ 0.774 , $\mathrm{P}$ value $<0.001)$.

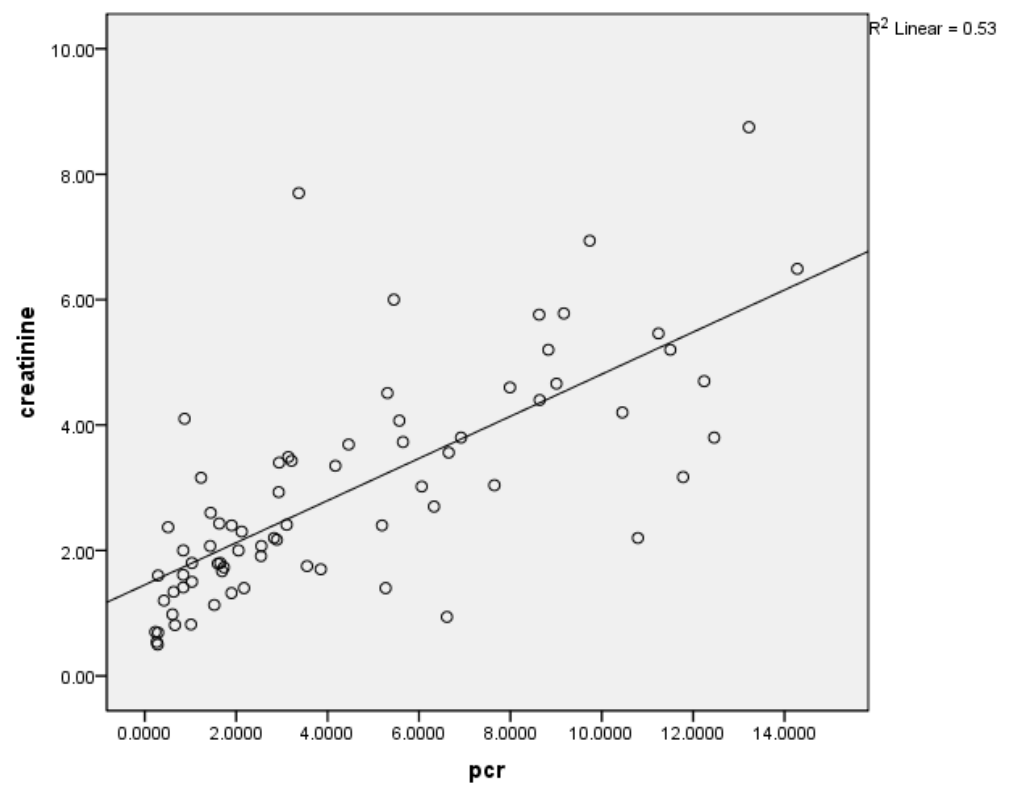

Chart 15 : correlation between urine PCR and creatinine $(\mathrm{mg} / \mathrm{dL})$

$$
\begin{aligned}
& \text { Correlation coefficient }(r): 0.774 \\
& \text { P value }:<0.001
\end{aligned}
$$

\section{Correlation between $24 \mathrm{Hr}$ Urine Protein and Serum Creatinine}

There was significant positive correlation between serum creatinine and $24 \mathrm{hr}$ urine protein in our study population $(\mathrm{r}=0.656$, $\mathrm{p}$ value $<0.001)$.

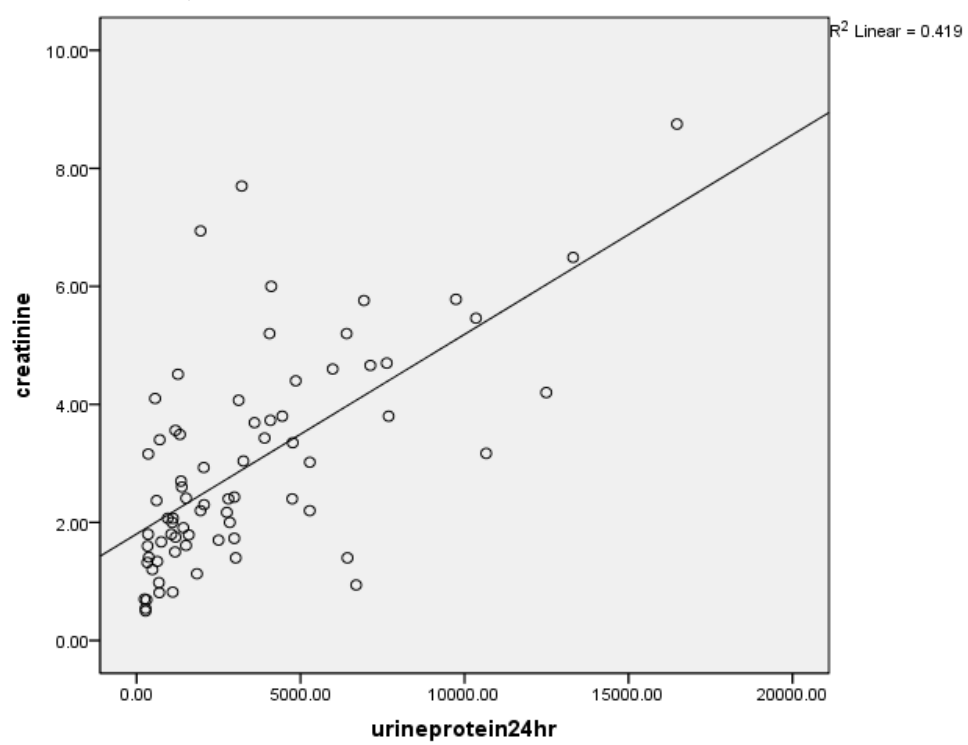

Chart 16 : correlation between $24 \mathrm{hr}$ urine protein and creatinine

Correlation coefficient (r): 0.656

$P$ value : $<0.001$ 


\section{Correlation between Urine PCR and HBA1C}

There was no significant correlation between urine PCR and HBA1C levels $(r=0.076, p$ value 0.956)

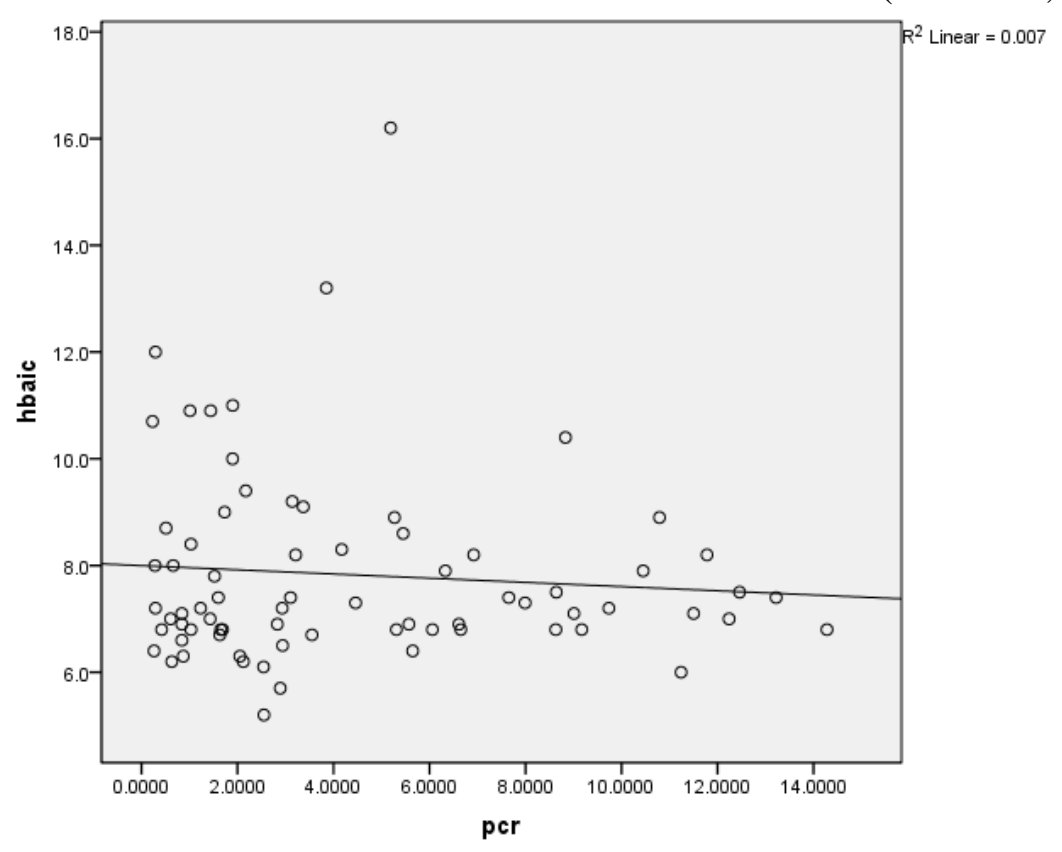

Chart 17 : Correlation between urine PCR and HBA1C

Correlation coefficient $(\mathrm{r}): 0.007$

$P$ value : 0.956

\section{Correlation between $24 \mathrm{Hr}$ Urine Protein and HBA1C}

There was no significant correlation between urine PCR and HBA1C levels $(r=0.076$, $p$ value 0.52$)$

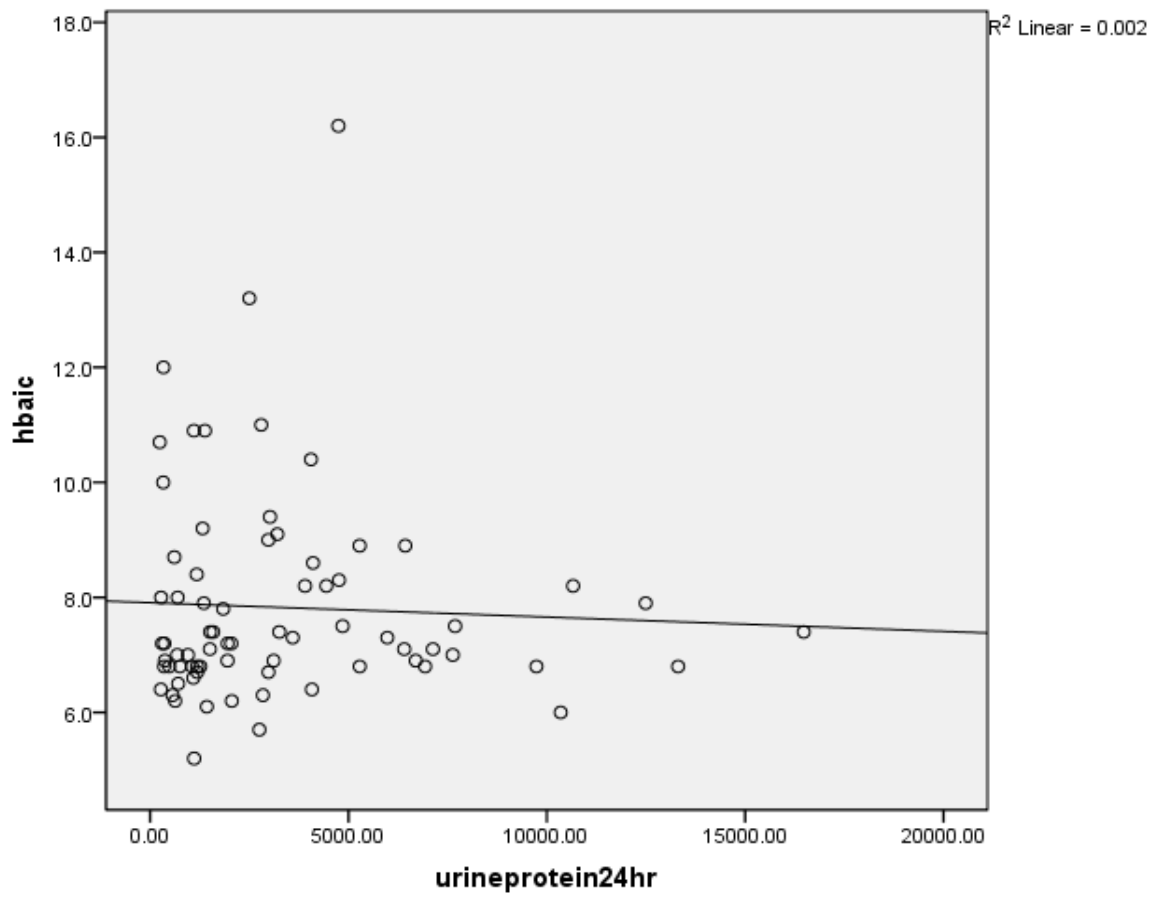

Chart 18 : correlation between $24 \mathrm{hr}$ urine protein and HBA1C

Correlation coefficient (r) : 0.076

$P$ value : 0.52 


\section{JMSCR Vol||06||Issue||06||Page 412-425||June}

\section{Correlation between Urine PCR and Retinopathy}

There was a good correlation between degree of diabetic retinopathy and urine PCR in our study.

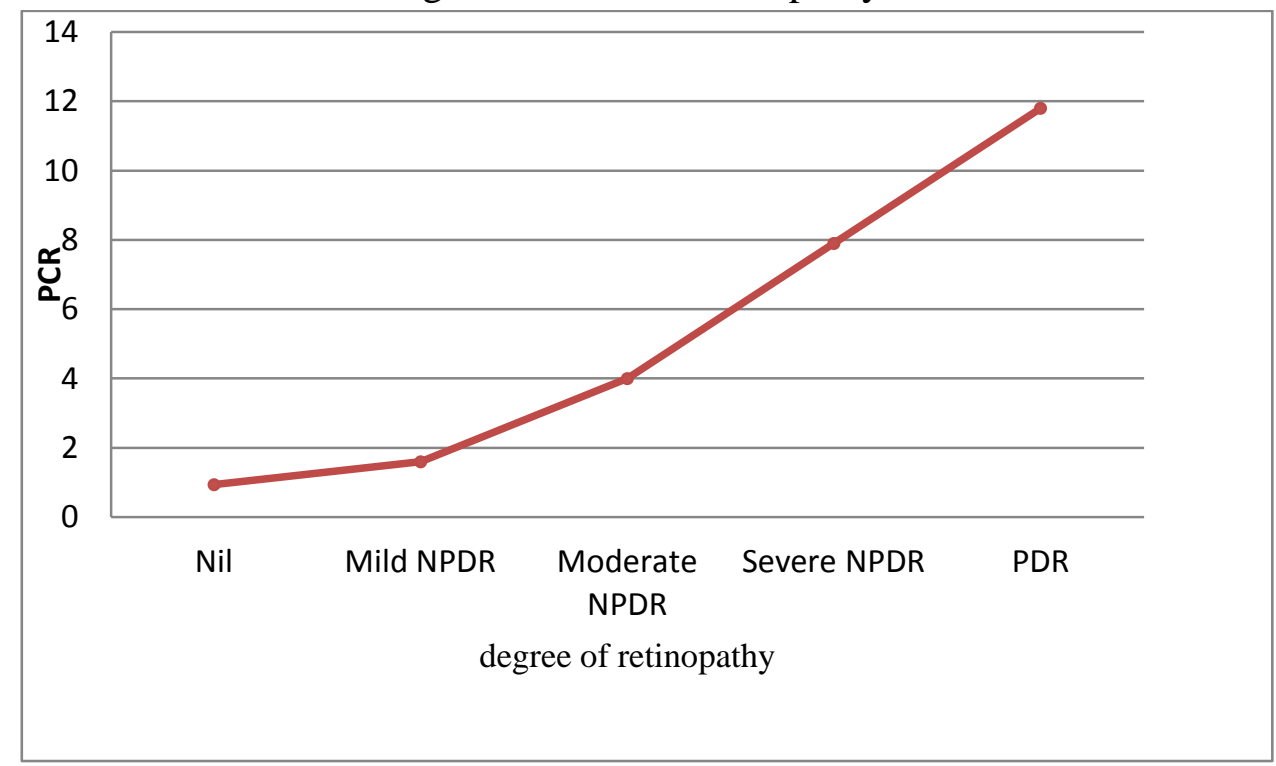

Chart 19 : correlation between urine PCR and degree of retinopathy

\begin{tabular}{|l|l|l|l|l|}
\hline Degree of retinopathy & $\begin{array}{l}\text { Median } \\
\text { pcr }\end{array}$ & \multicolumn{2}{|l|}{ Quartiles } & \multirow{2}{*}{ P value } \\
\cline { 1 - 3 } & Q1 & Q3 & \\
\hline Nil & 0.94 & 0.38 & 1.33 & \\
\hline Mild NPDR & 1.60 & 0.84 & 2.17 & \\
\hline Moderate NPDR & 4.01 & 3.19 & 5.34 & $<0.001$ \\
\hline Severe NPDR & 7.9 & 6.63 & 8.91 & \\
\hline PDR & 11.7 & 11.01 & 12.84 & \\
\hline
\end{tabular}

Association between urine PCR and retinopathy

\section{Conclusion}

In this study of 73 patients with type 2 diabetes mellitus and proteinuria, it was found that:

- Maximum number of patients were noted in the age group 41-50 years.

- Males were more than females in the ratio of 2.04:1

- Majority of patients had a duration of diabetes between $5-10$ yrs $(52.05 \%)$.

- The mean duration of diabetes was $9.24+/-$ 6.1 yrs.

- Ten patients (13.7\%) did not have diabetic retinopathy.

- Twenty five patients (34.25\%) had nephrotic range proteinuria.
- There was good correlation between urine PCR and $24 \mathrm{hr}$ urine protein at different levels of GFR.

- Maximum correlation between urine PCR and $24 \mathrm{hr}$ urine protein was seen in the GFR >60 group.

- There was good correlation between urine PCR and $24 \mathrm{hr}$ urine protein at different ranges of proteinuria.

- Maximum correlation between urine PCR and $24 \mathrm{hr}$ urine was seen in the proteinuria group <300.

- There was good correlation between urine PCR and serum creatinine. 
- No statistically significant correlation was found between HBA1C levels and degree of proteinuria.

- There was no significant correlation between urine PCR and duration of diabetes.

- There was good correlation between degree of diabetic retinopathy and proteinuria.

- So urine protein creatinine ratio can replace $24 \mathrm{hr}$ urine protein estimation in the screening and evaluation of diabetic nephropathy.

\section{Bibliography}

1. Shaw JE, Sicree RA, Zimmet PZ. Global estimates of the prevalence of diabetes for 2010 and 2030. Diabetes Res Clin Pract 2010; 87: 4-14.

2. Akmal M. Hemodialysis in diabetic patients. Am J Kidney Dis 2001; 38 (4 Suppl 1): S195-S199.

3. Price CP, Newall RG, Boyd JC. Use of protein:creatinine ratio measurements on random urine samples for prediction of significant proteinuria: a systematic review. Clin Chem.2005;51(9):1577-86.

4. Methven S, MacGregor MS, Traynor JP, O'Reilly DJ, Deighan CI. Assessing proteinuria in chronic kidney disease: protein-creatinine ratio versus albumincreatinine ratio. Nephrol Dial Transplant. 2010;25(9):2991-6.

5. Stevens LA, Levey AS. Current status and future perspectives for CKD testing. American Journal of Kidney Diseases. 2009;53(3):S17-S26.

6. Ahmed AM. History of diabetes mellitus. Saudi Med J 2002. Apr;23 (4):373-378.

7. Alebiosu CO, Kadiri S, Akang EEU. Clinicopathological study of Diabetic Nephropathy based on Renal Biopsy. Diabetes Intemational. 2002;12:66-69.
8. Kimmestiel $\mathrm{P}$, Wilson $\mathrm{C}$. Intercapillary lesions in the glomeruli of the kidney. Am J Path. 1936;1 2:83-97.

9. Mora-Fernández C, Domínguez-Pimentel V, de Fuentes MM, et al. (2014). "Diabetic kidney disease: from physiology to therapeutics". J. Physiol. 592 (18): 39974012.

10. Ding Y, Choi ME (January 2015). "Autophagy in diabetic nephropathy". $J$ Endocrinol. 224.

11. Lizicarova D, Krahulec B, Hirnerova E, Gaspar L, Celecova Z (2014). "Risk factors in diabetic nephropathy progression at present". Bratisl Lek Listy. 115 (8): 517-21.

12. Pálsson R, Patel UD (2014). "Cardiovascular complications of diabetic kidney disease". Adv Chronic Kidney Dis. 21 (3): 273-80.

13. Mongessen CE. Renal function changes in diabetes. Diabetes. 1976;15 (Suppl 2):872879.

14. American Diabetes Association. Diabetic Nephropathy (Position Statement). Diabetes Care. 2002;25(Suppl 1 ):S85S89.

15. Remmuzi G, Schiepatti A, Ruggenenti P. Nephropathy in patients with type-2 diabetes. NEJM. 2002;346:1145-1151.

16. Ritz E, Orth SR. Nephropathy in patients with type-2 diabetes mellitus. NEJM 1999;341:1127-1133.

17. Caramori ML, Fioretto P, Mauer M: The need for early predictors of diabetic nephropathy risk: is albumin excretion rate sufficient? Diabetes 2000, 49:1399-1408.

18. Perkins BA, Ficociello LH, Silva KH, Finkelstein DM, Warram JH, Krolewski AS: Regression of microalbuminuria in type 1 diabetes. $N$ Engl $J$ Med 2003, 348:2285-2293.

19. Dinneen SF, Gerstein HC: The association of microalbuminuria and mortality in noninsulin-dependent diabetes mellitus. A 
systematic overview of the literature. Arch Intern Med 1997, 157:1413-1418.

20. Stehouwer CD, Gall MA, Twisk JW, Knudsen E, Emeis JJ, Parving $\mathrm{HH}$ : Increased urinary albumin excretion, endothelial dysfunction, and chronic lowgrade inflammation in type 2 diabetes: progressive, interrelated, and independently associated with risk of death. Diabetes 2002, 51:1157-1165.

21. Viberti GC, Bilous RW, Mackintosh D, Keen H: Monitoring glomerular function in diabetic nephropathy. A prospective study. Am J Med 1983, 74:256-264.

22. Gall MA, Nielsen FS, Smidt UM, Parving $\mathrm{HH}$ : The course of kidney function in type 2 (non-insulin-dependent) diabetic patients with diabetic nephropathy. Diabetologia 1993, 36:1071-1078.

23. Friedman R, Gross JL: Evolution of glomerular filtration rate in proteinuric NIDDM patients. Diabetes Care 1991, 14:355-359.

24. Nosadini R, Velussi M, Brocco E, Bruseghin M, Abaterusso C, Saller A, Dalla Vestra M, Carraro A, Bortoloso E, Sambataro M, Barzon I, Frigato F, Muollo B, Chiesura-Corona M, Pacini G, Baggio B, Piarulli F, Sfriso A, Fioretto P: Course of renal function in type 2 diabetic patients with abnormalities of albumin excretion rate. Diabetes 2000, 49:476-484.

25. Krolewski AS, Warram JH, Christlieb AR, Busick EJ, Kahn CR: The changing natural history of nephropathy in type I diabetes. Am J Med 1985, 78:785-794.

26. Krolewski AS: Genetics of diabetic nephropathy: evidence for major and minor gene effects. Kidney Int 1999, 55:1582-1596.

27. Krolewski AS, Ng DP, Canani LH, Warram JH: Genetics of diabetic nephropathy: how far are we from finding susceptibility genes? Adv Nephrol Necker Hosp 2001, 31:295-315.
28. Quinn M, Angelico MC, Warram JH, Krolewski AS: Familial factors determine the development of diabetic nephropathy in patients with IDDM. Diabetologia 1996, 39:940-945.

29. Pettitt DJ, Saad MF, Bennett PH, Nelson RG, Knowler WC: Familial predisposition to renal disease in two generations of Pima Indians with type 2 (non-insulindependent) diabetes mellitus. Diabetologia 1990, 33:438-443.

30. Freedman BI, Tuttle AB, Spray BJ: Familial predisposition to nephropathy in African-Americans with non-insulindependent diabetes mellitus. Am J Kidney Dis 1995, 25:710-713.

31. Clustering of long-term complications in families with diabetes in the diabetes control and complications trial. The Diabetes Control and Complications Trial Research Group Diabetes 1997, 46:18291839.

32. Canani LH, Gerchman F, Gross JL: Familial clustering of diabetic nephropathy in Brazilian type 2 diabetic patients. Diabetes 1999, 48:909-913.

33. Ritz E, Orth SR. Nephropathy in patients with type-2 diabetes mellitus. NEJM 1999;341:1127-1133.

34. Krowleski AS. Genetics of diabetic nephropathy: evidence for major and minor gene effects. Kidney Int. 1999;55:1582-1596.

35. Pettitt DJ, Saad MF, Bennett PH, et al. Familial predisposition to renal disease in two generations of Pima Indians with type2 (noninsulin-dependent)diabetes mellitus. Diabetologia. 1990; 33:438-443.

36. Gall M-A, Hougaard P, Borch-Johnsen K, et al. Risk factors for development of incipient and overt diabetic nephropathy in patients with noninsulin- dependent diabetes mellitus: prospective observational study. BMJ.1997; 314:783-788. 
37. Ravid M, Neumann L, Lishner M. Plasma lipids and the progression of nephropathy in diabetes mellitus type-2: effect of ACE inhibitors. Kidney Int.1995; 47:907-910.

38. Hovind P, Rossing P, Tarnow L, et al. Progression of diabetic nephropathy. Kidney Int. 2001; 59:702-709.

39. Cooper ME. Pathogenesis, prevention, and treatment of diabetic nephropathy. Lancet. 1998; 352:213-219.

40. Predictors of the development of microalbuminuria in patients with Type 1 diabetes mellitus: a seven-year prospective study. The Microalbuminuria Collaborative Study Group Diabet Med 1999, 16:918-925.

41. Ravid M, Brosh D, Ravid-Safran D, Levy Z, Rachmani R: Main risk factors for nephropathy in type 2 diabetes mellitus are plasma cholesterol levels, mean blood pressure, and hyperglycemia. Arch Intern Med 1998, 158:998-1004.

42. The Diabetes Control and Complications Trial Research Group. The effect of intensive treatment of diabetes on the development and progression at long-term complications in insulin-dependent diabetes mellitus. NEJM 1993:329:977986.

43. United Kingdom Prospective Diabetes Study (UKPDS) Group. Intensive blood glucose control with sulphonylureas or insulin compared with conventional treatment and risk of complications in patients with type-2 diabetes (UKPDS 33). Lancet. 1998; 352:837-853 [Erratum. Lancet. 1999; 354:602].

44. Mulec H, Blohme G, Grandi B, et al. The effect of metabolic control on rate of decline in renal function in insulindependent diabetes mellitus with overt diabetic nephropathy. Nephrol Dial Tronspoant. 1998;13:651-655.

45. Park JY, Kim HK, Chung YE, Kim SW, Hong SK, Lee KU: Incidence and determinants of microalbuminuria in Koreans with type 2 diabetes. Diabetes Care 1998, 21:530-534.

46. Arauz-Pacheco C, Parrott MA, Raskin P. The treatment of hypertension in adult patients with diabetes. Diabetes Care. 2002;25:134-147.

47. American Diabetes Association. Treatment of hypertension in adults with diabetes. Diabetes Care. 2003;26(Suppl 1 ):S80S82.

48. Ruggenenti P, Remuzzi G: Nephropathy of type-2 diabetes mellitus. $J$ Am Soc Nephrol 1998, 9:2157-2169.

49. Loon NR. Diabetic kidney disease: preventing dialysis and transplantation Clinical Diabetes. 2003;21:55-62.

50. Jeffers BW, Estacio RO, Raynolds MV, et al. Angiotensin-converting enzyme gene polymorphism in noninsulin-dependent diabetes mellitus and its relationship with diabetic nephropathy. Kidney Int.1997; 52:473-477.

51. Biesenbach G, Zazgornik J. Influence of smoking on the survival rate of diabetic patients requiring hemodialysis. Diabetes Care. 1996;19:635-638.

52. Klein R, Klein BEK, Moss SE, et al. The 10 -year incidence of renal insufficiency in people with type-I diabetes. Diabetes Care. 1999; 22:743-751.

53. Chaturvedi N, Fuller JH, Taskinen MR: Differing associations of lipid and lipoprotein disturbances with the macrovascular and microvascular complications of type 1 diabetes. Diabetes Care 2001, 24:2071-2077.

54. Loon NR. Diabetic kidney disease: preventing dialysis and transplantation. Clinical Diabetes. 2003;21:55-62.

55. Jeffers BW, Estacio RO, Raynolds MV, et al. Angiotensin-converting enzyme gene polymorphism in noninsulin-dependent diabetes mellitus and its relationship with 
diabetic nephropathy. Kidney Int.1997; 52:473-477.

56. Kuramoto N, Lizuka T, Ito H, et al. Effect of ACE gene on diabetic nephropathy in NIDDM patients with insulin resistance. Am J Kidney Dis.1999; 33:276-28 1.

57. Kunz R, Bork JP, Fritsche L, et al. Association between the angiotensin converting enzyme insertion/deletion polymorphism and diabetic nephropathy. A methodologic appraisal and systematic review. J Am Soc Nephrol. 1998; 9:16531663.

58. Shah VO, Scavini M, Nikolic J, et al. Z-2 microsatellite allele is linked to increased expression of the aldose reductase gene in diabetic nephropathy. $J$ Clin Endocrinol Metab. 1998;83:2886.

59. Pugh JA, Stern MP, Haffner SM, et al. Excess incidence of treatment of end-stage renal disease in Mexican Americans. Am J Epidemiol. 1998;127:135-144.

60. Brancati FL, Whittle JC, Whelton PK, et al. The excess incidence of diabetic endstage renal disease among blacks. A population-based study of potential explanatory factors JAMA 1992;268:30793084.

61. Fioretto P, Caramori ML, Mauer M: The kidney in diabetes: dynamic pathways of injury and repair. The Camillo Golgi Lecture. Diabetologia 2007, 51:13471355.

62. Pezzolesi MG, Poznik GD, Mychaleckyj JC, Paterson AD, Barati MT, Klein JB, Ng DP, Placha G, Canani LH, Bochenski J, Waggott D, Merchant ML, Krolewski B, Mirea L, Wanic K, Katavetin P, Kure M, Wolkow P, Dunn JS, Smiles A, Walker WH, Boright AP, Bull SB, Doria A, Rogus JJ, Rich SS, Warram JH, Krolewski AS: Genome-wide Association Scan for Diabetic Nephropathy Susceptibility Genes in Type 1 Diabetes Mellitus. Diabetes 2009.
63. Brosius FC 3rd: New insights into the mechanisms of fibrosis and sclerosis in diabetic nephropathy. Rev Endocr Metab Disord 2008, 9:245-254.

64. Dronavalli S, Duka I, Bakris GL: The pathogenesis of diabetic nephropathy. Nat Clin Pract Endocrinol Metab 2008, 4:444452.

65. Nosadini R, Velussi M, Brocco E, Bruseghin M, Abaterusso C, Saller A, Dalla Vestra M, Carraro A, Bortoloso E, Sambataro M, Barzon I, Frigato F, Muollo B, Chiesura-Corona M, Pacini G, Baggio B, Piarulli F, Sfriso A, Fioretto P: Course of renal function in type 2 diabetic patients with abnormalities of albumin excretion rate. Diabetes 2000, 49:476-484.

66. Thomas MC,. Lai KN, Tang SCW. Pathogenesis and Progression of Proteinuria: Diabetes and the Kidney. Contrib Nephrol. 2011; 170: 48-56.

67. Singh A, Satchell SC, Neal CR, McKenzie EA, Tooke JE, Mathieson PW. Glomerular endothelial glycocalyx constitutes a barrier to protein permeability. $J$ Am Soc Neph-rol. 2007; 18(11):2885-93.

68. Pan CY, Ho LT, Soegondo S, Prodjosudjadi W, Suwanwalaikorn S, Lim SC, Chan TM, Chow KW, Thoenes M, Choi DS; DEMAND Study Investigators. Prevalence of albuminuria and cardiovascular risk profile in a referred cohort of patients with type 2 diabetes: an Asian perspective. Diabetes Technol Ther. 2008; 10(5):397-403.

69. Dalla Vestra M, Saller A, Bortoloso E, Mauer M, Fioretto P. Structural involvement in type 1 and type 2 diabetic nephropathy. Diabetes Metab. 2000; 26 Suppl 4:8-14.

70. Sharma K, Eltayeb BO, McGowan TA, Dunn SR, Alzahabi B, Rohde R, Ziyadeh FN, Lewis EJ:Captopril-induced reduction of serum levels of transforming growth factor-beta1 correlates with long-term 
renoprotection in insulin-dependent diabetic patients. Am $J$ Kidney Dis 1999, 34:818-823.

71. Welsh GI, Hale LJ, Eremina V, et al. Insulin signaling to the glomerular podocyte is critical for normal kidney function. Cell Metab 2010; 12(4):329.

72. Fornoni A .Proteinuria, the podocyte, and insulin resistance diabetes mellitus Type 2 and proteinuria. N Engl J Med 2010;363 (21):2068. 